\section{Anxiety state of the pregnant women in Serbia with gestational diabetes mellitus class A1}

Tatjana Perovic ${ }^{1}$, Dragan Savkovic ${ }^{2}$, Miroslava Gojnic Dugalic ${ }^{3}$, Milan Perovic ${ }^{4}$, Minja Stankovic ${ }^{4}$, Dragana Bojovic Jovic ${ }^{4}$, Zeljana Marinkovic ${ }^{5}$

${ }^{1}$ Clinical Hospital Center „Zvezdara”, Belgrade, Serbia

${ }^{2}$ Hospital „Sveti Vraci”, Bjeljina, Bosnia and Herzegovina

${ }^{3}$ Clinic for Gynecology and Obstetrics, Clinical center of Serbia, Belgrade, Serbia

${ }^{4}$ Clinic for Gynecology and Obstetrics „Narodni front”, Belgrade, Serbia

${ }^{5}$ Health Center „Pozarevac”, Pozarevac, Serbia

\section{Abstract}

The psychological impact of developing gestational diabetes mellitus (GDM) has been investigated widely in both children and adults. Although these studies suggest that person who develop GDM is at risk for emotional/ psychological distress, this finding is not universal. The aim of our study was to look at the state of anxiety in the group of pregnant women with well controlled GDM class A1 patients at 36 weeks of gestation and to compare it with the healthy controls at the same gestational age in population of pregnant women in Belgrade, Serbia. The study was carried on in 48 pregnant women with GDM and 80 healthy controls. The anxiety state of the two groups was evaluated with Hamilton Anxiety Scale (HAMA). The incidence rate of anxiety in the pregnant women with GDM were $27.03 \%$ (13/48), and in the healthy pregnant women $13.75 \%(11 / 80)$. The incidence rate of anxiety in pregnant women with GDM was higher significantly than control group, and there were significant difference in total score and its factorial score of HAMA in the two groups. The incidence rate of anxiety in the pregnant women with GDM is higher, and anxiety is the dangerous factor of GDM. Psychological state in pregnant woman, especially in pregnant women with GDM must be noticed, and psychological counseling and psychological therapy may be carried on as early as possible.

Key words: gestational diabetes, anxiety

\section{Procena anksioznosti trudnica sa gestacionim dijabetesom klase A1 u Srbiji}

Tatjana Perović ${ }^{1}$, Dragan Savković 2 , Miroslava Gojnić Dugalić3 ${ }^{3}$, Milan Perović ${ }^{4}$, Minja Stanković ${ }^{4}$, Dragana Bojović Jović 4 , Željana Marinković ${ }^{5}$

${ }^{1}$ Kliničko-bolnički centar „Zvezdara”, Beograd, Srbija

${ }^{2}$ Bolnica „Sveti Vrači”, Bijeljina, Bosna i Hercegovina

3 Klinika za ginekologiju i akušerstvo, Klinički centar Srbije, Beograd, Srbija

${ }^{4}$ Klinika za ginekologiju i akušerstvo „Narodni front”, Beograd, Srbija

${ }^{5}$ Zdravstveni centar „Požarevac”, Požarevac, Srbija

\section{Apstrakt}

Psihološke konsekvence pojave gestacionog dijabetesa (GDM) su ispitani kod trudnica i njihovog potomstva. Iako većina studija sugeriše da osobe sa GDMom imaju rizik nastanka emocionalnog i psihološkog distresa, ovaj zaključak nije univerzalan.

Cilj studije je da ispita nivo anksioznosti u grupi dobro kontrolisanih trudnica sa GDMom klase A1 u 36. nedelji trudnoće i uporedi ga sa zdravom populacijom trudnica iste gestacione starosti. Studija je izvedena u 48 trudnica sa GDM-om i 80 zdravih trudnica.

Nivo anksioznosti ispitivan je sa Hamilton Anxiety Scale (HAMA). Incidenca anksioznosti trudnica sa GDM-om je bila $27.03 \%$ (13/48) i 13.75\% (11/80) kod zdravih trudnica, a potvrđena je statistička značajnost ove razlike. Anksioznost je značajno je veća $\mathrm{u}$ obolelih nego u zdravih trudnica.

Zato se blagovremeno mora uočiti anksioznost trudnica sa GDM-om, a kako bi psihološko savetovanje i eventualna terapija bili što ranije primenjeni.

Ključne reči: gestacioni dijabetes, anksioznost

\title{
Introduction
}

Anxiety disorders in the perinatal period have received more research attention recently. Current findings indicate that symptoms of anxiety are common during pregnancy and the postpartum period1 and those maternal symptoms of anxiety during pregnancy are associated with adverse fetal and developmental consequences2. The psychological impact of developing gestational diabetes mellitus (GDM) has been investigated widely in both children and adults. Although these studies suggest that person who develop gestational diabetes is at 
risk for emotional/psychological distress, this finding is not universal ${ }^{3}$. These conflicting findings result from a number of factors, including different study population (impaired glucose tolerance, GDM class A1, GDM class A2), different gestational weeks among study participants, different percentage of well-controlled versus poorly controlled diabetics in the sample etc. For this reasons the aim of our study was to look at the state of anxiety in the group of pregnant women with well controlled gestational diabetes mellitus class A1 patients at 36 weeks of gestation and to compare it with the healthy controls at the same gestational age in population of pregnant women in Belgrade, Serbia.

\section{Materials and Methods}

The study was carried on in 48 pregnant women with GDM and 80 healthy controls recruited in Clinic for Gynecology and Obstetrics, Clinical center of Serbia, during the study period from February $1^{\text {st }}, 2012$ to July $1^{\text {st }} 2012$. Women who have experienced GDM in previous pregnancies, those with multiple pregnancies, with other diseases in pregnancies, those with fetal congenital anomalies were excluded from the study. The general data of the two groups were collected, and the anxiety state of the two groups was evaluated with Hamilton Anxiety Scale (HAMA) at 36 weeks of pregnancy. Working group consisted of women with GDM who were at that time period evaluated by regular control of and control group consisted healthy pregnant women at regular check up of the pregnancy status. Data is expressed as mean values with standard deviation, or as median with interquartile ranges for skewed data. Categorical data is presented in absolute numbers with percentages and analyzed using chi-square test and Fisher's exact test. For continuous variables, Student's $t$-test or the MannWhitney U-test was used. Logistic Regression Analysis was performed to evaluate the relationship between anxiety and the presence or absence of GDM. A P value of $<0.05$ was considered statistically significant.

\section{Results}

The characteristics of the study population are presented at the table 1 . There were no significant differences in all the observed characteristics of the participants in two groups, $\mathrm{p}>0.05$.

\begin{tabular}{|l|l|l|l|}
\hline \multirow{2}{*}{ Variable } & GDM & Control group & \multirow{2}{*}{} \\
\cline { 2 - 4 } & $\mathrm{N}(\%)$ & $\mathrm{N}(\%)$ & \\
\hline Age (Year)* & $29.73 \pm 5.011$ & $30.17 \pm 5.192$ & 0.435 \\
\hline Nulliparity & $26(54.2)$ & $43(53.8)$ & 0.335 \\
\hline Secundigravida & $15(31.2)$ & $27(33.7)$ & 0.023 \\
\hline Tercigravida & $4(8.3)$ & $6(7.5)$ & 0.145 \\
\hline Multiparity & $3(6.3)$ & $4(5)$ & 0.031 \\
\hline Primary school level & $8(16.7)$ & $15(18.7)$ & 0.022 \\
\hline High school level & $24(50)$ & $41(51.3)$ & 0.256 \\
\hline University level & $16(33.3)$ & $24(30)$ & 0.153 \\
\hline Family history of diabetes & $26(54.1)$ & $42(52.5)$ & 0.122 \\
\hline Obesity & $4(8.3)$ & $7(8.75)$ & 0.241 \\
\hline Marital status & $32(66.6)$ & $57(71.2)$ & 0.06 \\
\hline
\end{tabular}

Table 1. Characteristics of study population

*; age is presented as $\mathrm{X} \pm \mathrm{SD}$. 
The incidence rate of anxiety in the pregnant women with GDM were $27.03 \%$ (13/48), and in the healthy pregnant women $13.75 \%(11 / 80)$. The incidence rate of anxiety in pregnant women with GDM was higher significantly than control group $(<0.05)$, and there were significant difference in total score and its factorial score of HAMA in the two groups. With Logistic regression, it was found that the risk factors of GDM were the weeks of pregnancy, Body Mass Index (BMI) of pregnant woman, the condition of family economy and total score of HAMA.

\section{Discussion}

In our culture, pregnancy and childbirth are usually connected with optimistic emotions and with motherhood, but the fact is that this is not the case for all women or for all pregnancies. Our study addresses a different feature of these reproductive events, focusing on stressful circumstances surrounding pregnancy complicated with GDM, when the pregnancy itself becomes a stressful life event. Because of the dangers associated with gestational diabetes for both mother and child, diagnosis of the condition can be distressing 4 .

After controlling for age, marital status, income, BMI, and gravida, education level, women with GDM were 2.7 times more likely to have anxiety (when measured by the HAMA anxiety scale), which was statistically and clinically significant. Our findings are in accordance with a number of other studies which suggest that persons who develop GDM are at risk for anxiety, emotional and psychological distress ${ }^{5,6}$. But this finding is not universal. The results of the study of Spirito and colleagues suggest that the majority of pregnant women adapt readily to the unexpected diagnosis of GDM3. Therefore, caring out a research with a larger study population in the future would be of a great importance.

\section{Literatura}

1. Eccles R. Evaluation of the Nasal Airway and Nasal Challenge in : Kerr A, editor. Scott-Brown`s Otolaryngology.6th ed. Oxford: Butterworth-Heinemann; 1997. p 4/4/5-8

2. Passali D, Mezzedimi C, Passali GC, Nuti D, Bellussi L. The role of rhinomanometry, acoustic rhinometry, and mucociliary transport time in the assessment of nasal patency. Ear Nose Throat J. 2000;79(5):397-400.

3. Pallanch JF, McCaffrey TV, Kern EB. Evaluation of nasal breathing function with objective airway testing. In: CW Cummings, JM Fredrickson, LA Harker, et al,, eds. Otolaryngology: Head and Neck Surgery. 3rd ed. St. Louis, MO: Mosby-Year Book, Inc; 1998:803-809.

4. Akoğlu E, Karazincir S, Balci A, Okuyucu S, Sumbas H, Dağli AS. Evaluation of the turbinate hypertrophy by computed tomography in patients with deviated nasal septum. Otolaryngol Head Neck Surg. 2007;136(3):380-4.

5. Janda P, Sroka R, Baumgartner R, Grevers G, Leunig A. Laser treatment of hyperplastic inferior nasal turbinates: a review. Lasers Surg Med. 2001;28(5):404-13.

6. Barbosa Ade A, Caldas N, Morais AX, Campos AJ, Caldas S, Lessa F. Assessment of pre and postoperative symptomatology in patients undergoing inferior turbinectomy. Braz J Otorhinolaryngol. 2005;71(4):468-71.

Autor za korespondenciju:

Andrej Grubor

Služba za ORL i MF, KBC Zemun Vukova 9, Zemun 